\title{
LEITURA SEMIÓTICA DO TEMPLO DE SALOMÃO E O CONSUMO DA FÉ
}

\author{
Semiotic's reading of the Temple of Salomon and the \\ consumption of the faith
}

\author{
Lectura semiótica del Templo de Salomón y consumo \\ de la fe
}

\author{
Lucia Santaella \\ Pontifícia Universidade Católica, São Paulo, Brasil \\ Professora titular na Pós-Graduação em Comunicação e Semiótica e coordenadora da \\ Pós-Graduação em Tecnologias da Inteligência e Design Digital (PUC-SP). Doutora em Teoria Literária \\ pela PUC-SP e livre-docente em Ciências da Comunicação pela USP. E-mail: Ibraga@pucsp.br
}

\author{
Carla Dendasck \\ Pontifícia Universidade Católica, São Paulo, Brasil \\ Doutora em Psicanálise Clínica pela Faculdade Internacional de Teologia (FIT), doutoranda \\ em Comunicação e Semiótica pela PUC-SP. Mestre em Ciências da Religião pela Universidade \\ Presbiteriana Mackenzie. E-mail: cdendasck@hotmail.com
}

\author{
Danielle Ferraro \\ Pontifícia Universidade Católica, São Paulo, Brasil \\ Mestranda em Comunicação e Semiótica pela PUC-SP. E-mail: dany.ferraro@gmail.com
}

\begin{abstract}
RESUMO O Templo de Salomão, na cidade de São Paulo, surpreende por seu gigantismo e luxo faraônico. Surpreende igualmente pelo grande número de fiéis que atrai para seus rituais. Este artigo tem por propósito colocar esse signo arquitetônico, sua temporalidade, suas referências, seus discursos e seus símbolos sob o escrutínio da semiótica de C. S. Peirce. Esta funciona aqui como uma cartografia cognitiva capaz de orientar a compreensão da complexidade que o signo Templo de Salomão envolve. O mais importante, contudo, é que a complexidade desse signo advém da hipercomplexidade de seu campo de referências históricas milenares, que a semiótica chama de objeto signo. Nessa medida, este artigo procede uma jornada histórica rumo à coleta da densidade desse campo, a saber, daquilo que, na semiótica, recebe o nome de experiência colateral com o objeto do signo. Como resultado, esta análise pretende ser capaz de orientar o leitor à compreensão das camadas de sentido que se sobrepõem na constituição do signo complexo Templo de Salomão.
\end{abstract}

PALAVRAS-CHAVE Signo, Experiência colateral, Religião, Bíblia, Pentecostais.

\begin{abstract}
The Temple of Solomon, in the city of São Paulo, surprises for its giant size and pharaonic luxury. It is also surprising for the large number of believers it attracts to its rituals. This article aims to place this architectural sign, its temporality, its references, its discourses, and its symbols under the scrutiny of C. S. Peirce's semiotics. This theory works here as a cognitive cartography capable of guiding the understanding of the complexity involved by the sign Temple of Solomon. The most important, however, is that the complexity of this sign derives from the hypercomplexity of its field of millenary
\end{abstract}


historical references, a kind of field that semiotically functions as the object of the sign. To that extent, this article proceeds on a historic journey towards collecting the density of this field, namely, what, in semiotics, is called collateral experience with the object of the sign. As a result, this analysis aims to be able to guide the reader towards the understanding of the layers of meaning that overlap in the constitution of this complex sign Temple of Solomon.

KEYWORDS Sign, Collateral experience, Religion, Bible, Pentecostals.

RESUMEN El Templo de Salomón de la ciudad de São Paulo sorprende por su tamaño y lujo faraónico. Además de la gran cantidad de creyentes que atrae a sus rituales. Este artículo tiene el propósito de analizar este signo arquitectónico, su temporalidad, sus referencias, sus discursos y sus símbolos a partir de la semiótica de C. S. Peirce. Esto se considera como una cartografía cognitiva capaz de orientar la comprensión de la complejidad que implica el signo Templo de Salomón. Lo más importante es que su complejidad proviene de la hipercomplejidad de su campo de referencias históricas milenarias, un campo de referencias que la semiótica denomina objeto-signo. En esa medida, este artículo realiza un recorrido histórico hacia la recogida de la densidad de este campo, es decir, llamado en semiótica de experiencia colateral con el objeto-signo. Se espera que este análisis pueda auxiliar al lector a comprender las capas de significado que se superponen en la constitución de ese complejo signo del Templo de Salomón.

PALABRAS-CLAVE Signo, Experiencia colateral, Religión, Biblia, Pentecostales.

O propósito deste artigo é desenvolver uma leitura semiótica do Templo de Salomão, construção realizada pela Igreja Universal do Reino de Deus (IURD) em São Paulo sob o comando de seu fundador, Edir Macedo. Esse templo, com dimensões e luxo faraônicos, situa-se na Avenida Celso Garcia, no Bairro do Brás, na capital paulista (Figura 1). Foi construído sob inspiração do templo bíblico de mesmo nome, localizado em Jerusalém.

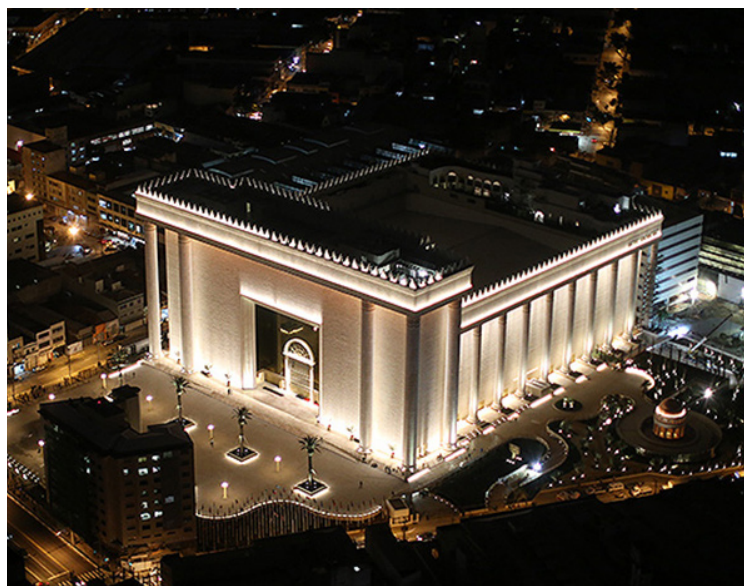

Figura 1. Templo de Salomão da Igreja Universal do Reino de Deus

Fonte: Visão Cristã (2016)!

Entre as várias tendências da semiótica, aquela que foi escolhida para esta leitura é a de C. S. Peirce. Acredita-se que um dos pontos mais importantes nas escritas contemporâneas, especialmente nas escritas acadêmicas, ou naquelas que se propõem a fazer algum tipo

1. Disponível em: https://visaocrista.com.br/revista/tag/templo-de-salomao/. Acesso em: 29 jun. 2021. 
de análise ou reflexão profunda, seja desprender tempo na tentativa de esclarecer ao leitor os conceitos que estão sendo considerados. É claro que o conceito ou os conceitos nem sempre são tão fáceis de se esclarecer, e, como já diriam Deleuze e Guattari (1992, p. 27): "não há conceito simples. Todo conceito tem componentes, e se define por eles”. Ora, a semiótica peirciana é conhecida pela abstração da teia de conceitos que aciona. Tendo isso em vista, sem deixar de atentar para a complexidade da tarefa, em lugar de uma apresentação introdutória dos conceitos principais da teoria geral dos signos, iremos brevemente definir esses conceitos à medida que forem sendo acionados pela análise, portanto, pari passu com suas aplicações.

Central na semiótica peirciana é a noção de signo. De modo simplificado, este se define como algo que está em lugar de outra coisa, que é chamada de objeto do signo. Por ter essa função representativa ou mediadora, o signo está apto a provocar um efeito interpretativo tão logo encontre um intérprete. Nessa perspectiva, o Templo de Salomão é, sem dúvida, um signo. Contudo, por ser um templo inspirado na Bíblia, que não se limita a sua natureza arquitetônica, mas destinado a usos ritualísticos, carregados de símbolos de natureza milenar, além de múltiplas facetas históricas e religiosas, é possível, de saída, declarar que se trata de um signo complexo, que tem como referente ou, para usarmos a terminologia peirciana, - um signo que está no lugar de um objeto hipercomplexo, sendo, consequentemente, capaz de produzir interpretações multifacetadas. Isso sinaliza o desafio que este artigo visa enfrentar para que se torne mais compreensível o poder de atração que esse templo e seu ideário conseguem despertar em seus fiéis, e, também, para orientar aqueles que pretendem desenvolver um pensamento crítico acerca desse estado de coisas.

\section{O SIGNO EM SI MESMO}

Nossa análise inicia-se pelo olhar contemplativo para o signo, olhar para ele tal como se apresenta. Tendo por base as categorias fenomenológicas de primeiridade (possibilidade, qualidade, sentimento), secundidade (existente, ação-reação, dualidade) e terceiridade (lei, hábito, continuidade), todo signo em si mesmo apresenta três facetas interrelacionadas: é uma qualidade em si mesma, é também um existente e, igualmente, uma lei representativa.

Comecemos pelo quali-signo. "O primeiro deve ser indeterminado, e o primeiro indeterminado de alguma coisa é o material de que é formado" (CP 1.373). Ou ainda: "o signo diz o que diz, antes de tudo, através do modo como aparece, tão somente através de suas qualidades” (SANTAELLA, 2018, p. 29). Neste caso, consideramos como aspectos de quali-signo todas as características da construção do Templo de Salomão: as pedras importadas de Israel que foram utilizadas na fachada, a cor dourada aplicada em diversos detalhes, a imitação da Arca da Aliança, as cadeiras importadas da Espanha, as oliveiras centenárias importadas do Uruguai, as tamareiras de Israel, as bandeiras de tantos países hasteadas.

Segundo reportagem de Rodrigo Cardoso (2014) para a revista Isto É, o templo tem 100 mil metros quadrados de área construída - mais que o triplo do tamanho do Santuário de Aparecida do Norte, o maior santuário católico do Brasil - e 54 metros de altura, o equivalente a um prédio de onze andares. Foram importados quase 40 mil metros quadrados 
de pedras da cidade israelense de Hebrom. As cadeiras, importadas da Espanha, custaram cerca de 22 milhões de reais. A esplanada do templo tem altas tamareiras que vieram de Israel e, segundo o site da IURD, "fazem referência à passagem bíblica: o justo florescerá como a palmeira” (2021).

O complexo tem capacidade para mais de 10 mil pessoas sentadas e ainda 36 salas de escola bíblica, estúdios de televisão e rádio, auditório para 500 pessoas, estacionamento para quase 2 mil carros, um memorial que traz a história dos templos antigos e do povo hebreu, com réplicas dos artefatos sagrados originais, além de 59 apartamentos quitinete e vinte apartamentos com uma ou duas suítes. Tudo isso são propriedades do quali-signo que enchem os olhos e sugerem grandiosidade, poder, exuberância, ostentação, sucesso.

Passemos para o aspecto de sin-signo, ou seja, como as propriedades de composição do templo estão corporificadas e situadas no tempo e no espaço. O Templo de Salomão, sede mundial da IURD, ganha forma pela referência, no início do século XXI, em uma das maiores metrópoles da América Latina, ao Templo de Salomão de Jerusalém, portanto, um lugar de instanciação da fé religiosa e de manutenção da espiritualidade. A construção do Templo ocorreu entre 2010 e 2014 e apresenta números impactantes. O custo total da construção foi estimado em 680 milhões de reais. Segundo Barbosa (2017), parte do valor foi financiado pelas doações de fiéis da IURD. Tais pedidos de doações eram frequentes e apareciam em discursos do bispo Edir Macedo, conforme o mote: "aqueles que contribuírem, aqueles que lutarem, aqueles que se esforçarem para contribuir, para nos ajudar, vão ser ricos” (BARBOSA, 2017).

A Igreja Universal passou a erguer imponentes catedrais em diversas capitais do país, como parte de uma estratégia para construir uma imagem religiosa mais respeitável e de maior prestígio, conforme reportagem de Cardoso (2014). Entretanto, nada que se compare ao Templo de Salomão. O jornal The New York Times, na época da inauguração, descreveu o Templo como um símbolo poderoso em dois aspectos: o Brasil, que se torna símbolo do epicentro global do Pentecostalismo, e a Igreja Universal como símbolo da principal congregação que desafia a Igreja Católica no país (ROMERO, 2014). Portanto, esse signo arquitetônico não se limita a sua existência tempo-espacial, mas encarna leis milenares (legi-signos) da religiosidade cristã e de sua base no judaísmo, conforme será analisado nas relações simbólicas a que os legi-signos remetem.

Os elementos acima delineados são pontos de partida, e a análise ficaria muito pobre se, do signo em si, não avançasse para a relação que este mantém com seu objeto de referência. Uma vez que, sem dúvida, se trata de um objeto hipercomplexo, pois remete a séculos de travessia da religiosidade cristã e dos rastros que foi deixando pelo caminho, o intérprete que ora se propõe a realizar a leitura semiótica desse templo, ou seja, gerar interpretantes do signo-templo - a saber, as autoras desta leitura -, necessitam praticar aquilo que a semiótica peirciana chama de experiência colateral com o objeto do signo. Esse é um quesito "bastante indispensável ao funcionamento do signo", pois "ele não pode ser completamente revelado ou trazido à luz por qualquer estudo do signo unicamente como tal. O conhecimento sobre ele deve vir de alguma fonte prévia ou colateral" (SANTAELLA, 2020, p. 77). No que se segue, portanto, iremos realizar a longa jornada de rastreio, ou melhor, de desenvolvimento da experiência colateral com o objeto do signo Templo de Salomão. 


\section{A EXPERIÊNCIA COLATERAL COM O OBJETO DO SIGNO}

Buscamos construir um panorama contextual histórico, com algumas bases conceituais à medida que o texto for apresentado. Assim, esse signo arquitetônico, o Templo de Salomão, carrega consigo mensagens que vão muito além daquela que imaginamos em um primeiro momento, seja de forma direta ou indireta, seja pelos membros da IURD ou apenas por intérpretes afetados por ela, os quais, mesmo não conhecendo seus fundamentos, acabam sendo impactados pelos signos que esta aciona. Quer dizer, mesmo que a experiência colateral, que será colocada em evidência a seguir, não seja de conhecimento dos intérpretes, os signos Templo de Salomão e seus enunciadores, a IURD e suas tradições, são capazes de produzir os mais variados interpretantes, e entre os fiéis, especificamente, interpretantes de fé e adesão.

A jornada da experiência colateral não deixa de ser uma jornada por múltiplos signos e sistemas de signos, que ocupam a posição de objetos do signo Templo de Salomão - daí sua hipercomplexidade. Para isso, optou-se por dividir o percurso em três tópicos principais. O primeiro está mais próximo de nós, e versa sobre a religiosidade no Brasil e a influência que a religião tem na composição da mentalidade brasileira, fazendo uma breve consideração sobre os que são considerados “evangélicos”, com referência aos neopentecostais, e sobre como o cristianismo, apesar de considerar a Bíblia como um livro sagrado em todas as suas facetas, acaba por adotar discursos e padrões de comportamentos diferenciados, com diferentes teologias e dogmas. A importância desse breve panorama consiste em aproximar o leitor dos conceitos e concepções adotados nesta análise semiótica.

Já o segundo momento traz alguns aspectos históricos da Igreja Universal do Reino de Deus, aproveitando também para apresentar a figura de seu fundador, Edir Macedo, traçando alguns pressupostos que possivelmente afetaram a escolha do discurso adotado pela igreja e que, certamente, impulsionaram a criação da obra arquitetônica do Templo de Salomão. Por fim, retornamos à leitura semiótica para examinar os aspectos icônicos, indiciais e simbólicos do Templo de Salomão e fazer algumas considerações sobre os interpretantes que esse signo está apto a produzir, o que até certo ponto pode ser previsto por meio da leitura semiótica.

\section{CONSIDERAÇÕES SOBRE A RELIGIOSIDADE NO BRASIL}

Não só o Brasil, mas todos os países europeus ou colonizados por europeus trazem em sua história, e, portanto, na formação de seu pensamento social, uma forte influência da religião, especialmente do cristianismo, adotado como religião oficial de Roma por volta de 380 d.C. Apesar de hoje serem identificadas hibridizações ou atuações de outros tipos de religião que não têm base cristã, como o budismo, o islã e outras tradições orientais, o Brasil ainda é um país fortemente cristão, onde as principais religiões são representadas pelo catolicismo, protestantismo, espiritismo e religiões com raízes africanas. Mas a maioria das vertentes adotam aspectos católicos em sua composição, logo, pensamentos cristãos.

O censo do Instituto Brasileiro de Geografia e Estatística (IBGE) de 2010 considerou a religiosidade no Brasil como dividida nas seguintes classes: católicos romanos; outras religiosidades; evangélicos pentecostais 
e neopentecostais; espíritas; sem religião; evangélicos não determinados; evangélicos de missão; umbandistas e candomblecistas (Figura 2).

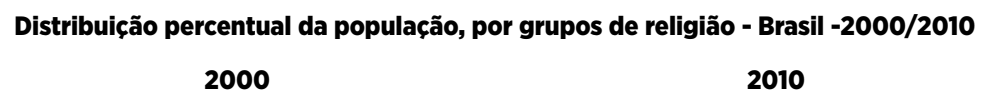

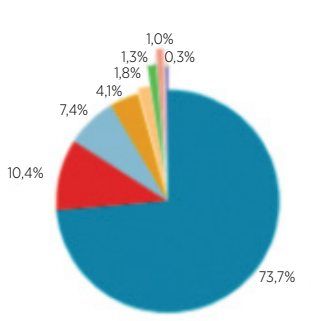

Católicos romanos

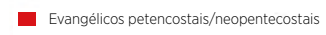

Espiritas

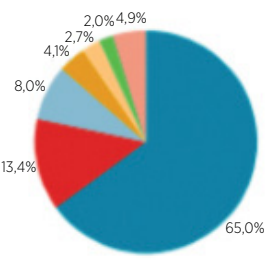

Sem religiāo

Evangélicos năo determinados
Evangélicos de Missăo

- Umbandistas e candomblecistas

Figura 2. Religiosidade no Brasil

Fonte: IBGE (2010).

Se somarmos as religiões de base cristã, excluiremos apenas as classes dos sem religião e outras religiosidades, que somariam cerca de $10 \%$, restando cerca de $90 \%$ dos brasileiros declarando religiões de matrizes cristãs. Deve-se ainda ressaltar que os $2,7 \%$ que se dizem de outras religiosidades estão sujeitos às influências e hibridizações do contato com o cristianismo.

Evidenciar a herança cristã no pensamento ocidental para a análise do signo aqui em questão é tão ou mais importante do que o fenômeno neopentecostal (o qual será reportado mais adiante), pelo fato de todas as religiões provenientes do cristianismo considerarem a Bíblia um livro sagrado, que fundamenta suas respectivas fés, mesmo que, com base na mesma Bíblia, exista milhares de interpretações que induzem a dogmas diferentes, gerando novas religiões. É nesse livro sagrado, compartilhado entre as religiões de base cristã, que vamos encontrar a história de várias sociedades, especialmente a base da história judaica, que se inicia na gênese.

Basicamente, a compilação de pergaminhos organizada como Bíblia Sagrada divide-se em Antigo e Novo Testamento. O recorte se dá com o nascimento de Jesus Cristo, que, apesar de não ser reconhecido pelo judaísmo como o messias prometido para o povo de Deus, passou a ser o alicerce da igreja cristã, e até mesmo influenciar movimentos judaicocristãos ou judaico-messiânicos. Entender os desdobramentos bíblicos certamente é fundamental para compreender a hipercomplexidade semiótica do objeto cuja experiência colateral estamos rastreando. Isso porque tudo desemboca no "representante de Deus na terra", ou ainda no "homem que salva o povo de Deus", justamente $o$ significado máximo de poder que a construção de uma cópia do templo original de Salomão busca trazer.

Desde que o casal Adão e Eva sucumbiu à tentativa de ser igual a Deus, comendo o fruto proibido e introduzindo o pecado (a maldade) no mundo terrestre (Gênesis 3), tem início uma história longa de constantes erros da espécie humana, especialmente devido a sua maldade e desobediência a Deus. Por outro lado, surge a misericórdia de Deus, concedida através de alianças que são constantemente quebradas e religadas. No livro de Gênesis, quando Deus se arrepende de ter criado o homem, pensando 
em desfazer Sua criação, é através de um homem (Noé) que, ao lançar o dilúvio na terra e livrar apenas Noé e seus descendentes, encontra-se a primeira representação da aliança de Deus com Noé, após a saída da arca e o início de um novo pacto de obediência (Gênesis 9, 1-16). Ainda no mesmo livro, mais uma vez a raça humana desaponta Deus. No entanto, surge Abraão, que, por conta de sua obediência, é designado por Deus como pai de todas as nações, originando as doze tribos de Israel.

Os primeiros livros do Velho Testamento (Gênesis, Êxodo, Levítico, Números, Deuteronômio), também conhecidos como pentateuco, são até hoje utilizados pelos judeus, e serão usados como firmamento histórico para esta análise. Pois é especialmente neles que se inicia a história das alianças entre Deus e o homem, bem como decorre a decadência das gerações, que sempre são salvas através de um homem, como Jacó, que consegue o que quer graças a ser obediente, e gera José, que se tornará governador do Egito para salvar o povo de Deus (israelitas). É através de José que os israelitas chegaram ao Egito, fugindo assim da fome que assolou sua terra por sete anos. No entanto, ao chegarem ao Egito, os israelitas mais uma vez desobedecem aos ordenamentos do Deus de Israel, sendo então castigados com a escravidão.

No livro de Êxodo, com o crescimento da quantidade de israelitas no Egito, o governador prevê um domínio desses estrangeiros, ordenando então a morte dos meninos judeus. No segundo capítulo do livro de Êxodo, Deus, agora evocado por alguns israelitas, lembra-se da aliança que fez com o povo de Israel e salva Moisés, colocando-o para ser criado dentro do palácio para libertar os israelitas do Egito. Esse mesmo povo é sustentado por Deus no deserto durante 40 anos, a fim levá-los “à terra prometida"2. No período em que os israelitas vagavam pelo deserto, Deus estabeleceu os dez mandamentos, que vão servir como um manual de conduta e impor uma série de leis que os israelitas devem cumprir. São exemplos o uso de tendas especialmente instaladas para cultos e rituais diversos, leis com relação a rituais como a Páscoa, sacrifícios, uso de incensos e de artefatos de metais nobres (ouro e cobre). Cria ainda o ministério sacerdotal, instruindo a utilização de roupas especiais, e firma sua aliança com o povo de Deus instruindo a criação da Arca da Aliança, que deveria guardar as tábuas dos dez mandamentos e servir como sinal da supremacia do Deus de Abraão sobre os demais povos e outros deuses.

No livro de Levítico, Deus continua orientando os israelitas com relação a rituais, comportamentos considerados pecaminosos, sacrifícios, cerimônias, festas, alimentação, conduta sexual, formato de ministérios de sacerdotes, dízimos e ofertas, dentre outras leis. O livro de Números, além de contar a população, explicita sua organização em doze tribos: Rúben, Simeão, Judá, Issacar, Efraim, Benjamim, Zebulon, Manassés, Dã, Aser, Naftai e Gade.

No livro de Deuteronômio, Deus então encaminha seu povo à cidade prometida, Canaã, instruindo os israelitas a guerrearem para conquistar esse território, que estava ocupado. Nesse momento, Deus mais uma vez analisa a fé e obediência dos israelitas, que entendem então que serão ricos e abastados em troca da obediência a Deus. Nos próximos livros do Antigo Testamento, encontramos a divisão das terras prometidas por Deus entre as doze tribos. Porém, a desobediência é retomada à medida que crescem essas sociedades, ao se misturarem com outras tradições e

2. É essa a base da disputa que ocorre até hoje sobre quem teria direito ao território de Israel, considerado sagrado por mulçumanos, judeus e cristãos. 
culturas, deixando de cumprir as leis estabelecidas na aliança com Deus. Mais uma vez, ao desobedecer a Deus, os israelitas entram em desgraça e, consequentemente, passam a perder guerras e batalhas. Em uma delas, os Filisteus roubam a Arca da Aliança como sinal de vitória sobre os israelitas. No entanto, Deus amaldiçoa os filisteus, e esse povo passa então a acumular uma série de maldições por deter a Arca da Aliança.

Em Samuel 6, 1-19, o rei filisteu manda devolver a Arca da Aliança aos israelitas, já que acreditava que todas as suas maldições vinham dela. Quando setenta homens, que não tinham permissão para olhar dentro da Arca da Aliança, tentaram abrir para ver o que tinha dentro, morreram instantaneamente, pois a Arca da Aliança envolvia justamente o sinal máximo da Aliança entre o próprio Deus Pai e o povo escolhido.

O Antigo Testamento segue com guerras, conquistas, maldições, reconciliações, até que Davi, homem que agradava a Deus, é feito rei de Israel e Judá, e a Arca da Aliança é então levada para Jerusalém. No livro de Reis, o filho de Davi, Salomão, vai ser feito rei de Israel - o mais rico e sábio da história bíblica. Todo o mérito de Salomão é atribuído a sua obediência a Deus, e em troca, detém não só sabedoria, mas domina inclusive as outras tribos de Israel, construindo então um templo, maior do que todos os templos, para exaltar a grandeza de Deus, com intuito não apenas de agradar a Deus, mas também de demonstrar seu poder como rei.

Depois de construído o Templo de Salomão, a Arca da Aliança é nele colocada e os rituais orientados a Moisés são religiosamente seguidos, garantindo assim a glória de Salomão sobre os demais reis e evidenciando a máxima de seu poder na terra, inclusive de ser chamado de representante de Deus (1 Reis 9). Há então outro corte, quando Salomão se afasta de Deus, especialmente pela desobediência à proibição de os israelitas se casarem com mulheres estrangeiras. 0 rei se casou com 700 princesas e 300 concubinas. A história de Israel de sua prevalência sobre os demais reinos termina quando os babilônicos conquistam Jerusalém e destroem o Templo de Salomão, que era o sinal de seu poder e riqueza.

Até o livro de Esdras, quando os israelitas voltam para Jerusalém e o Templo é reconstruído, esse povo divide-se entre obediência e desobediência a Deus e à aliança pré-estabelecida. Nesse período, surge uma série de profetas anunciando o "novo reino" com a vinda de um messias, que iria, finalmente, render de uma vez por todas os pecados da humanidade, resgatando definitivamente a aliança dos israelitas com Deus. No livro de Isaias, é possível encontrar várias passagens em que o profeta anuncia a vinda do messias ${ }^{3}$, além dos livros de Jeremias e Malaquias. A partir de então, há um período chamado de "interbíblico". Para os judeus, a história bíblica acaba nessa época, e até hoje eles esperam pelo messias.

O Novo Testamento inicia-se com a vinda de Jesus Cristo (a partir do Evangelho de Mateus), nascido da virgem Maria, criado em Nazaré, como diziam as profecias de Isaías, antecedido por João Batista, que pregava sobre a vinda do messias e a criação de um novo céu e terra. No entanto, diferentemente do que os judeus esperavam (ou seja, um rei como Salomão), Jesus Cristo traz outro tipo de fala, demonstra a simplicidade, o amor ao próximo, a felicidade através de uma mudança interior, a caridade, o não julgamento, as riquezas no céu e não na terra, dentre outros que envolvem fé e mudança comportamental, aproximando todos do Reino de Deus (Mateus; Marcos; João).

3. O livro de Isaías detém partes de profecias sobre a vinda do Messias para os judeus, dentre eles: Isaías 7, 14; 9, 6; 53. 
Os judeus daquela época, e a maioria dos judeus contemporâneos, não aceitaram que Jesus Cristo seria o messias, e por isso o mataram. Embora o discurso de Jesus Cristo não tenha sido bem aceito pelos judeus, entre outras razões, por ser abrangente, pautado em valores de inclusão e, de certa forma, em esperança para todos, ele passou a ser seguido por pessoas em todo o mundo, convertendo muitos fiéis, até se organizar como religião oficial de Roma, no ano de 380 d.C., sendo responsável, inclusive, pela mudança e uniformização do calendário que conhecemos hoje.

A partir de então, no ocidente, a religião católica se tornou predominante, sendo responsável pela coroação e escolha de reis na Europa até por volta dos anos 1500. Nessa época, se iniciou o movimento protestante, efetivado em 1517 com Lutero, abrindo espaço para uma série de outras religiões cristãs. Desde esse período, essas denominações se espalharam e chegaram ao Brasil com diversas ramificações e vertentes, como demonstra a Figura 3.

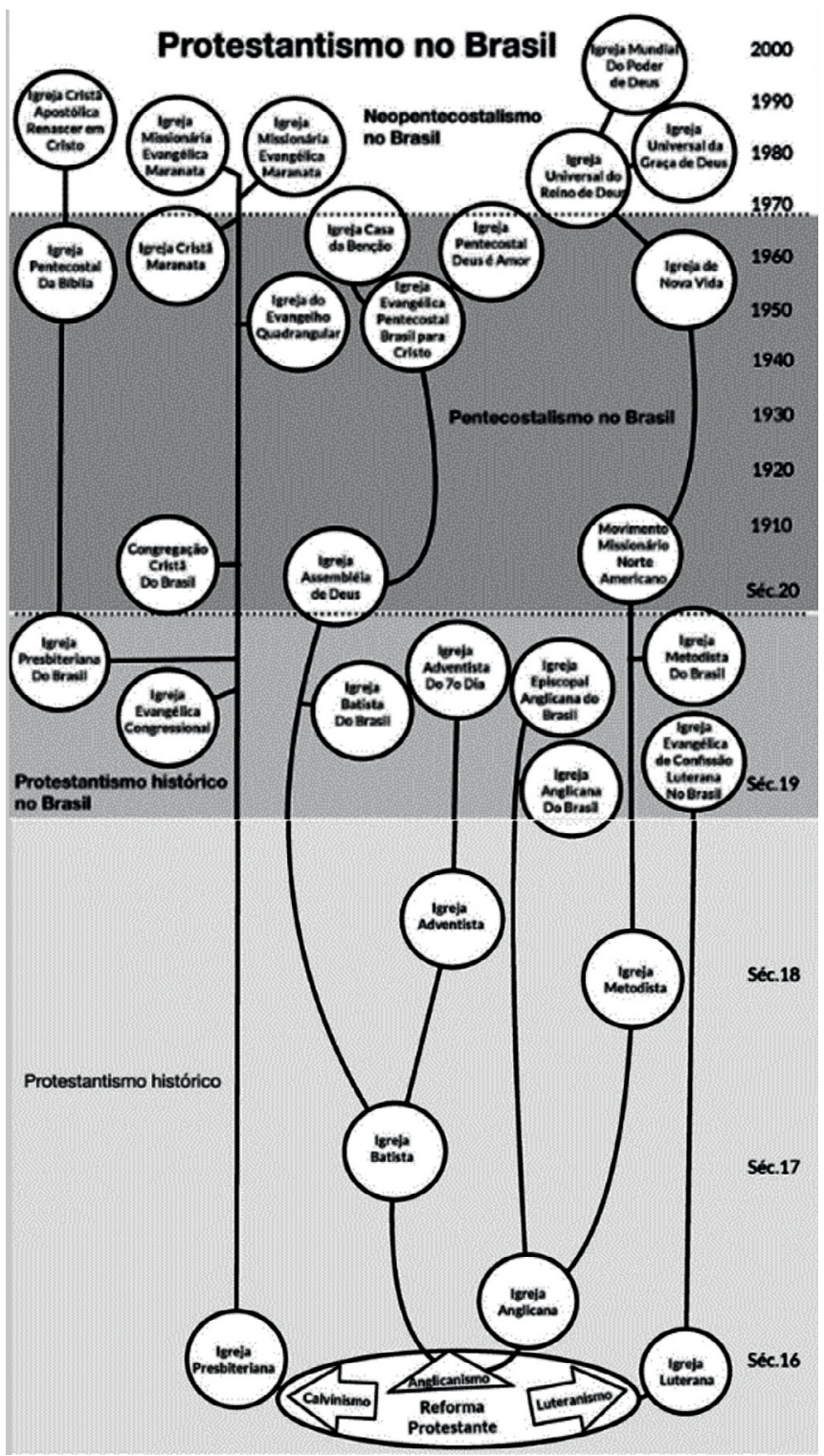

Figura 3. Protestantismo no Brasil 
Para além das diferenças entre católicos e protestantes e suas diversas ramificações, especialmente no que diz respeito às teologias doutrinárias, encontra-se a história bíblica da herança judaica. É por conta dessa origem comum que o Templo de Salomão construído por Edir Macedo se apresenta como um signo impactante de forma direta e indireta, não apenas para a sociedade brasileira, mas também para outros cristãos.

\section{A IGREJA UNIVERSAL DO REINO DE DEUS}

Após explanar o contexto bíblico do Templo de Salomão original e da Arca da Aliança, cabe agora entender brevemente as razões pelas quais uma organização ou uma pessoa gastaria cerca de 680 milhões de reais para erguer uma obra arquitetônica como o Templo de Salomão atualmente, em uma zona popular de uma cidade da América Latina.

De acordo com Feltran (2020), durante muitos anos, a sociedade intelectual e política pouco se interessou pelas consequências ou abrangência do fenômeno neopentecostal, até o dia que esse movimento impulsionou rapidamente a eleição de um presidente. Concorda-se parcialmente com essa afirmação de Feltran, pois desde a década de 1970, muitos estudos sobre o tema foram desenvolvidos, mas por não serem considerados tão relevantes, acabaram esquecidos.

Apesar de parte das pessoas e dos estudos apontarem todos os protestantes como uma única classe de evangélicos, é preciso esclarecer a diferença teológica doutrinária entre protestantes reformados históricos e a doutrina dos pentecostais e neopentecostais. Enquanto os protestantes reformados, de base calvinista ou luterana, iniciaram sua organização ainda no século XVI, por volta de 1500, consolidando-se em 1517, os pentecostais surgiram a partir do século XX, em torno de 1910, e os neopentecostais apenas entre o final dos anos 1960 e início dos 1970. Essa estrutura e criação histórica vão influenciar diretamente sua composição teológico-dogmática e, consequentemente, ideológica, trazendo vertentes diversas de atuações e crenças coletivas.

No entanto, este estudo não se propõe a investigar as diferenças pormenorizadas no sentido teológico histórico e/ou dogmático, mas sim inspecionar o objeto hipercomplexo do signo Templo de Salomão. Dessa forma, será traçado um panorama do contexto neopentecostal da IURD, iniciado pelo pentecostalismo.

Esse movimento, criado por volta de 1910, visa resgatar, baseado no contexto da festa de Pentecostes (que se refere às experiências judaicas durante as festas e que aparece no Novo Testamento), a característica que se refere à descida do Espírito Santo sobre os discípulos e primeiros cristãos, quando eles falariam em outras línguas ${ }^{4}$ (DIAS, 2018).

Existe uma discordância na literatura acadêmica sobre o neopentecostalismo ser uma extensão do movimento pentecostal, ou ser considerado um novo evento, pois ao mesmo tempo que também acreditam que "falam em línguas dos anjos", adotaram a teologia da prosperidade em seu discurso, e uniram alguns rituais inexistentes na igreja pentecostal (SILVA, 2019). Para este estudo, concordamos com Silva Junior (2017) quando diz que a própria construção da palavra "neopentecostal" se

4. Há uma discussão teológica quanto ao "falar em outras línguas”. Enquanto uma vertente entende que seriam as outras línguas dos povos da época, outros entendem que é uma língua desconhecida, denominada "língua dos anjos”. 
refere ao novo pentecostal, já que suas bases de falar em língua e de cultos mais voltados à experiência são identificadas. Ademais, ao contrário das igrejas protestantes históricas, nas quais o pastor e/ou líderes precisam ter estudos específicos em suas respectivas áreas de atuação, os líderes das igrejas pentecostais não precisam de nenhuma formação específica, e os prenomes são definidos por eles próprios: pastor(as), bispo(a), sacerdote(isa), discípulo(a), dentre outras formas de organização, tomando como prioridade a adoção de discursos neoliberais.

No Brasil, as primeiras organizações pentecostais foram criadas por Luigi Francescon, Daniel Berg e Gunnar Vingren em 1910, sendo as igrejas Congregação Cristã do Brasil e Assembleia de Deus duas das primeiras. Posteriormente, em 1950, com a influência dos Estados Unidos e em razão da imigração dos missionários Harold Williams e Raymond Boatright para o Brasil, a segunda onda surgiu com a formação da Igreja do Evangelho Quadrangular por eles fundada. As práticas dessa denominação (uso de veículos de mídia e mensagem de cura divina) se tornaram, posteriormente, pilares para o movimento neopentecostal brasileiro, apontado como a terceira onda pentecostal que teve início na década de 1970 (SANTOS et al., 2017).

Dias (2018, p. 89) aponta que a "teoria das ondas" foi criada na tentativa de classificar esses grupos pentecostais conforme suas origens e características. Destaca-se que o termo "terceira onda” foi cunhado pelo importante líder neopentecostal estadunidense Charles Peter Wagner, em seu livro The Third Wave of The Holy Spirit.

Silva Junior (2017) afirma que o neopentecostalismo é considerado a terceira onda do pentecostalismo, definindo um corte históricoinstitucional no contexto pentecostal, com caráter inovador. Sua expansão e fortalecimento se deram a partir de meados dos anos 1970 até a década de 1990, destacando-se três instituições no Rio de Janeiro: a Igreja IURD, de 1977, a Igreja Internacional da Graça de Deus, de 1980, e a Igreja Cristo Vive, de 1986.

Silva (2015) por sua vez, identifica que o neopentecostalismo surgiu no Brasil como uma forma adaptada ao contexto histórico de grandes transformações sociais. Quer dizer, um período de urbanização e desenvolvimento dos meios de comunicação, que já alcançavam boa parte da população, de crise católica, crescimento da umbanda e colapso econômico. Assim, conforme o autor, ao passo que as igrejas da segunda onda se expandiam na região de São Paulo, as igrejas neopentecostais eram formadas por líderes cariocas, alcançando grande parte da população ao se adaptarem à cultura urbana refletida pela televisão e pela ética yuppie em um cenário de decadência econômica, populismo político e máfia do jogo.

Silva Junior (2017) identificou que o neopentecostalismo realizou uma ruptura teológica considerável em relação aos movimentos anteriores, uma vez que prevalecia a de que se habitava um mundo ruim e cheio de pecados à espera da salvação, enquanto o neopentecostalismo voltou-se para questões terrenas, econômicas e espirituais, temperadas de sentimentalismo. O autor cita ainda algumas características desse movimento, algumas bem adaptadas aos princípios do consumo moderno, nesse caso, ao consumo da fé, tais como "a acomodação aos valores mundanos, o caráter de empresa, com instituições religiosas burocratizadas" (a lógica é sempre a do cliente-fiel, ou, na terminologia do marketing, a fidelização do cliente-consumidor), "a guerra contra o diabo e a teologia da prosperidade” (p. 66). 
Nesse contexto, Silva (2019, p. 30) aponta que esse movimento se caracteriza principalmente pelos seus "sinais e maravilhas, com fortes elementos mágicos; confrontos com poderes demoníacos e manifestações emocionais fortes; ensino da prosperidade e guerra espiritual”. Acrescenta que a ênfase ao dualismo é um fator diferencial entre esse movimento e os anteriores. Por consequência, sua crença se estabelece na ideia de que Deus quer o melhor para as pessoas, independente das áreas estruturais da vida. Para os neopentecostais, o "dom de línguas" se torna insignificante, enquanto são valorizados os "sopros” do Espírito, "arrebatamentos", "desmaios” e "multiplicidade de dons".

Dias (2018) ressalta que as igrejas neopentecostais têm emergido significativamente no campo religioso ao redor do mundo, em razão de sua forte introdução nos meios de comunicação, discursos sedutores e uma forma laica de se viver a vida religiosa. A teologia utilizada pelos neopentecostais se apoia em um discurso de prosperidade, do "você pode". No neopentecostalismo, o cristão deve viver livre de problemas; assim, ser cristão garante permanecer "liberto do diabo" e ganhar prosperidade.

Em sua gênese, o discurso neopentecostal alcançava, principalmente, os indivíduos menos favorecidos da população, que estavam em busca de respostas e soluções na religiosidade para os seus problemas cotidianos. Era-lhes pregado que seriam prósperos nesta vida se seguissem as palavras de Deus. No mundo moderno, o público se diversificou, expandindo-se por todo o território nacional (SILVA JUNIOR, 2017).

Santos et al. (2017) afirmam que o Brasil é um país predominantemente cristão, no qual o crescimento de igrejas pentecostais é significativo, com ênfase nos segmentos neopentecostais. A teologia neopentecostal defende a questão de benção financeira como um desejo de Deus. Ainda acrescenta que, para eles, se o crente é temeroso e fiel a Deus, consequentemente será próspero materialmente, em vista de os indivíduos serem destinados à vitória nessa vida, e não após a morte. Discurso, de resto, também adotado no Antigo Testamento.

Essa é justamente a base da Igreja Universal do Reino de Deus, em cuja criação Edir Macedo empregou o discurso da prosperidade e redenção para alcançar membros, especialmente nas periferias das grandes cidades. O discurso do retorno ao Antigo Testamento, ou seja, de um povo que sofre por se afastar de Deus, e como consequência vive as mazelas dos seus pecados na miséria e derrotas constantes, é adotado por Edir Macedo, contrapondo constantemente o retorno ao Pai, através da fidelidade à Igreja, aos rituais realizados, tendo como benefícios uma vida próspera e correta.

Tal discurso adotado por Edir Macedo, assim como as ações em prol da família, contra o alcoolismo e pela profissionalização, tem alcançado resultados positivos, especialmente nas periferias, já que o grande alvo dessa conversão acaba por ser as classes menos favorecida, tornando-se um movimento popular e com forte adesão pelas massas (SPYER, 2020).

Tendo em vista o rastreio da experiência colateral acima delineado, as relações objetuais icônicas, indiciais e simbólicas do signo Templo de Salomão se tornam mais ricas e bem fundamentadas.

\section{OS ASPECTOS ICÔNICOS, INDICIAIS E SIMBÓLICOS DO SIGNO TEMPLO DE SALOMÃO}

O signo possui dois objetos, o imediato e o dinâmico. O objeto imediato de um signo é o modo pelo qual aquilo que o signo representa, indica ou 
se assemelha está, de alguma maneira e em certa medida, presente no próprio signo (SANTAELLA, 2018, p. 32). Assim, o objeto imediato do signo Templo de Salomão é o modo como a Igreja Universal do Reino de Deus e toda sua história pregressa está encarnada nesse signo arquitetônico, tanto em sua relação icônica quanto indicial e simbólica com o objeto dinâmico, como será visto a seguir.

Abordar o objeto dinâmico do signo, por seu lado, conforme Santaella (2018, p. 34), significa falar do modo como o signo se reporta àquilo que ele intenta representar, indicar e se assemelhar. "O objeto dinâmico determina o signo, mas nós só temos acesso àquilo que o signo representa pela mediação do objeto imediato, interno ao signo”. Se não houvesse esse signo arquitetônico, signo síntese de uma longuíssima história, só teríamos acesso a essa história por meio de outros signos, sem o poder de síntese que esse signo arquitetonicamente monumental corporifica. Ainda em relação ao objeto dinâmico, Santaella (2018) define que há três modos através dos quais os signos se reportam aos seus objetos dinâmicos, a saber: o quali-signo é um ícone, o sin-signo é um índice e o legi-signo é um símbolo. Vejamos.

O Templo de Salomão da IURD é descrito, no site da igreja, como uma réplica do Templo de Salomão de Jerusalém, conforme os escritos sagrados da Bíblia. De acordo com Barbosa (2017, p. 27), Edir Macedo anunciou a construção do edifício da seguinte maneira: "Assim, a réplica do Templo de Salomão, edificada no Brasil, representa uma construção imaginada e projetada por Deus, que, no passado, O uniu com o Seu povo”. O bispo teve a ideia de construir sua imitação do templo durante uma peregrinação a Israel. O anúncio da construção ocorreu em 2010. Retomando o texto do Velho Testamento, procedeu-se na atualidade a construção de um templo maior do que todos os demais. A imagem do Templo de Salomão, seguindo os escritos bíblicos, está representada na Figura 4.

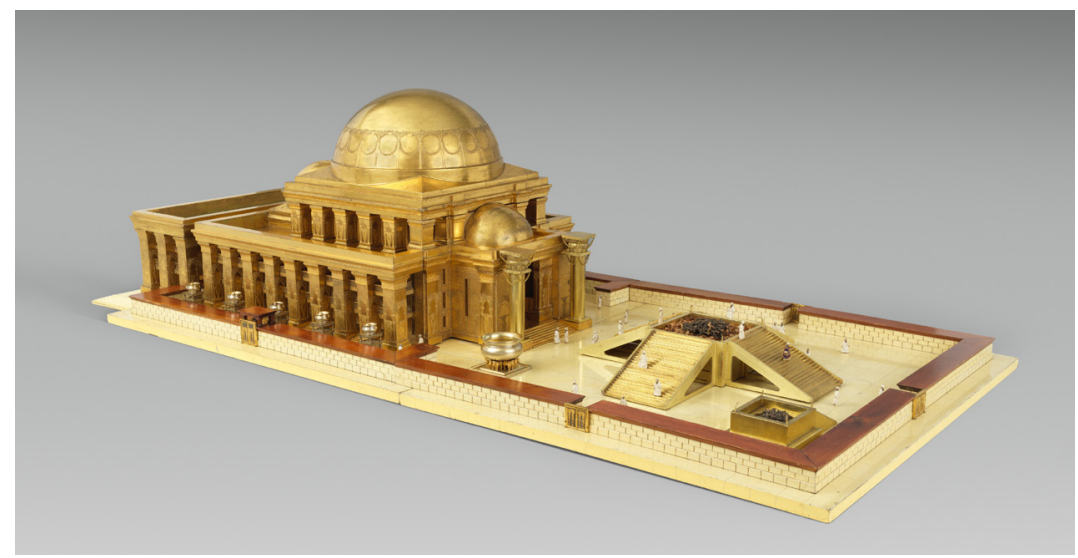

Figura 4. Modelo arquitetônico do templo do rei Salomão, em Jerusalem, 1883 Fonte: Met Museum.

Embora Edir Macedo se refira à construção arquitetônica do Templo de Salomão como uma réplica, a terminologia que caberia mais à instanciação é de um legi-signo, já que o que se estabelece é uma relação icônica com o templo original. O que se tem é uma imagem imitativa, uma "imitação" ou cópia. Portanto, o compósito de quali-signos atual busca apresentar relações de similaridade qualitativa, relações icônicas, com o antigo compósito de quali-signos do passado. Exemplo disso encontra-se no 
Jardim das Oliveiras, que possui doze unidades da árvore - cada uma com mais de cem anos, oriundas do Uruguai - para retratar o Getsemâni, no Monte das Oliveiras, local onde Jesus passou sua última noite antes de ser sacrificado. Já o Jardim Bíblico é uma réplica fiel ao Tabernáculo em escala original, seguindo a construção de 3 mil anos atrás.

Ademais, cada elemento qualitativo na composição arquitetônica externa e interna do templo funciona como um feixe de índices que remetem ao Templo de Salomão original: a construção, o tabernáculo, o dourado, as oliveiras e as tamareiras, a Arca da Aliança, toda sua materialidade. O índice maior está na fidelidade à história do templo original, desde o que o precedeu até sua consolidação, sob que circunstâncias e com quais finalidades. Foi esse denso feixe indexical que procuramos recuperar por meio da experiência colateral com o objeto do signo.

O ponto semiótico forte tanto do templo original quanto de sua imitação atual está nos legi-signos, que em relação aos seus objetos de referência, funcionam como símbolos. É vasto o elenco de símbolos dos quais depende o poder mítico, religioso, espiritual e ritualístico desse templo. Para começar, o Templo de Salomão funciona como o símbolo magno do poder da Igreja Universal do Reino de Deus, pois se institui como sede mundial da religião. A grande quantidade de bandeiras logo na entrada do templo representa os países em que a IURD está presente. Esse símbolo maior está alimentado de sub-símbolos, tais como a cor dourada, que segundo o próprio site da IURD, é predominante no templo por estar presente na Bíblia como utilizada nos objetos sagrados, simbolizando a natureza de Deus, imutável.

Também se destaca o candelabro de sete velas - dentro do templo e na entrada - entre outros símbolos judaicos, incluindo a bandeira de Israel. Segundo Romero (2014), a promoção do simbolismo judaico pela IURD em sua réplica do Templo de Salomão "decorre de uma busca por legitimidade histórica da jovem religião”. Além disso, a utilização de símbolos e rituais ligados ao Antigo Testamento e ao judaísmo serve para conquistar novos fiéis e seguidores e está implícita na simbologia de poder. A simbologia não para aí, pois tal denominação busca engrandecer seu poder por meio da encarnação indissolúvel no Templo de Salomão:

Edir Macedo coloca-se como o representante do Deus de Israel na Terra, quase se comportando como o Messias esperado pelos judeus, buscando constantemente simbolizar a aliança de Deus com o homem, como salvador da decadência das gerações que sempre são salvas através de um enviado-homem. (ROMERO, 2014)

O Novo Templo de Salomão busca simbolicamente a grandeza do antigo rei de Israel em seus dias de glória, e sua riqueza e suntuosidade são símbolos da sabedoria bem-sucedida, que provém da obediência e submissão a Deus, que retribui a fidelidade com bonança. Constitui-se, assim, uma versão contemporânea da teologia da prosperidade: quem é crente, temente e fiel a Deus, inclusive nos dízimos que paga, terá como retorno sua própria prosperidade material. A Arca da Aliança, que deveria guardar as tábuas dos dez mandamentos, serve também como índice e símbolo da supremacia do Deus de Abraão sobre os demais povos e deuses.

O retorno ao Velho Testamento e às heranças judaicas funciona como símbolo de que Deus continua orientando os israelitas com relação aos rituais, pecados, sacrifícios, cerimônias, festas, alimentação, conduta sexual, ministérios de sacerdotes, dízimos e ofertas, dentre outras leis. 
O valor simbólico dos dez mandamentos está expresso nas inúmeras instruções de Moisés para o cumprimento das leis estabelecidas, que trará riqueza, paz e alegria em troca da obediência e adoração monoteísta.

\section{OS INTERPRETANTES DO TEMPLO DE SALOMÃO}

Só em sua relação com os interpretantes, ou seja, nos efeitos interpretativos que produz nas mentes dos intérpretes, é que o signo funciona como tal. Antes de encontrar intérpretes e neles produzir signosinterpretantes, o signo é meramente potencial. Peirce estabeleceu três níveis do interpretante: o imediato, o dinâmico e o normal ou final.

O imediato está dentro do signo. Trata-se do nível de interpretabilidade do signo, ou seja, de sua capacidade de produzir interpretantes efetivos, e resguarda a objetividade do signo. Isso quer dizer que não se pode interpretá-lo por aquilo que ele não é, mas sim por seus modos de ser em si mesmo e pelas relações que mantém com seu objeto de referência o objeto dinâmico.

O interpretante dinâmico diz respeito aos signos-interpretantes que efetivamente são produzidos em mentes interpretadoras quando o signo chega a elas. Portanto, o interpretante não é o intérprete. Embora dependa dele, trata-se da tradução do signo recebido em um outro signo, o que depende do repertório do intérprete e de sua paciência interpretativa quando o signo implica, como no caso desta análise, uma exploração cuidadosa da experiência colateral com o objeto do signo.

Ao proceder a leitura semiótica de um signo, nesse ato, os sujeitos produzem interpretantes dinâmicos. Nessa medida, a leitura do signo Templo de Salomão funciona como um conjunto de interpretantes dinâmicos desse signo. Ademais, devido à exploração colateral do objeto do signo, esta leitura produz signos-interpretantes mais desenvolvidos que o próprio signo. Esclarecendo, todo signo é parcial. Seu objeto dinâmico é sempre mais vasto do que o próprio signo. Entretanto, o signo pode crescer em seus interpretantes à medida que o objeto do signo é rastreado, como se buscou aqui empreender.

A leitura do signo em si mesmo e de suas relações com o objeto também autoriza as autoras a prever os tipos de interpretantes que esse signo está apto a produzir, especialmente quando se sabe que o interpretante dinâmico se desdobra em três níveis: emocional, energético e lógico. O primeiro pode ser lido pelo apelo ao sentimento que o templo, seus símbolos e suas mensagens provocam nos fiéis. O templo em si cria uma atmosfera de suntuosidade, de misteriosa simbologia, de adoração e de ascese espiritual à grandeza de Deus. Não se pode esquecer que esses fiéis, muitas vezes abandonados pelo poder público, encontram na igreja condições de socialização, sentimento de pertencimento e amparo para alguns de seus problemas, como o alcoolismo, o desemprego e questões familiares.

$O$ interpretante energético manifesta-se na obediência aos mandamentos, na ação de frequência e acompanhamento dos rituais, que, de resto, incluem a oferenda dos dízimos. A promessa de retorno em riqueza como compensação pela obediência transforma todos os signos icônicos, indiciais e simbólicos em signos utilitários, que transmutam a fé e a religiosidade em ideologias de prosperidade dentro da lógica consumista das sociedades capitalistas modernas.

Por fim, no nível lógico, os fiéis absorvem as regras interpretativas, traduzindo em ações as palavras e regras mentalmente incorporadas 
como crenças. Conforme reza o pragmaticismo peirciano, os pensamentos entram pela porta da percepção e saem pela porta da ação deliberada (CP 5.212). Aos fiéis, entram pelas portas da percepção signos de grandiosidade e opulência como mediadores emocionais para a ascese espiritual. Uma ascese que depende da absorção e incorporação mental de signos ritualisticamente regrados como guias para a conduta. $O$ que as regras dissimulam é o interpretante lógico-mor, ou seja, a ascese cobra seu preço, não apenas em termos de obediência e veneração, mas também em termos do metal sonante, bem regido e adaptado aos padrões de consumo.

Se considerarmos que o interpretante final ou normal é aquele que sempre recua, pois corresponde à possibilidade nunca atingida de que o signo tenha alcançado todo o seu poder de significar, a leitura semiótica aqui empreendida se constitui, portanto, não obstante todo o esforço interpretativo nela envolvido, apenas em instanciações da potência significativa do signo Templo de Salomão. Isso se explica porque, no papel de intérpretes produtores de signos-interpretantes, estamos sempre no meio do caminho e nunca em posição de afirmar que tais signosinterpretantes aqui atualizados possam reivindicar qualquer finalismo. Todavia, podem reivindicar, isso sim, o empenho na busca de coerência e responsabilidade pelos interpretantes que gerou.

\section{REFERÊNCIAS}

BARBOSA, C. A. C. Jerusalém é aqui! Espaços de disputa e jogo de poder: o Templo de Salomão da lurd. 2017. Tese (Doutorado em Ciência da Religião) - Pontifícia Universidade Católica, São Paulo, 2017.

BÍBLIA SAGRADA. Tradução de Ferreira de Almeida. Barueri: Sociedade Bíblica do Brasil, 1988.

CARDOSO, R. A Meca dos Evangélicos. IstoÉ, São Paulo, 1 ago. 2014. Disponível em: https://bit.ly/2SkpWvi. Acesso em: 24 out. 2020.

DELEUZE, G.; GUATARRI, F. O que é Filosofia? Tradução de Bento Prado Jr. e Alberto Alonso Muñoz. São Paulo: Editora 34, 1992.

DIAS, J. C. T. O movimento pentecostal: algumas notas após os seus cem anos. Politeia: História e Sociedade, Vitória da Conquista, v. 18, n. 1, p. 77-94, 2018.

GOOGLE maps mostra terceiro templo em cima do monte do templo. Campina Grande: Visão cristã, 2 mar. 2017. Disponível em: https://visaocrista.com.br/revista/tag/templode-salomao/. Acesso em: 29 jun. 2021.

IGREJA Universal Templo de Salomão. São Paulo: lurd, 2021. Disponível em: https://bit.ly/ 2T173xy. Acesso em: 24 out. 2020.

INSTITUTO BRASILEIRO DE GEOGRAFIA E ESTATÍSTICA. Atlas do Censo Demográfico 2010. In: IBGE. Censo 2010. Rio de Janeiro: IBGE, 2010. p. 203. Disponível em: https://bit.ly/ 3f8zBOv. Acesso em: 21 maio 2021.

KING Solomon's tablet of stone. BBC Horizon, London, [23 set. 2004]. Disponível em: https://bbc.in/2Rv1rLS. Acesso em: 24 out. 2020.

PEIRCE, C. S. Collected papers. Cambridge: Harvard University Press, 1931-58. 8 v.

ROMERO, S. Temple in Brazil Appeals to a Surge in Evangelicals. The New York Times, New York, 24 jul. 2014. Disponível em: https://nyti.ms/3wsMUie. Acesso em: 24 out. 2020.

SANTAELLA, L. (org.). Charles Sanders Peirce: Excertos. São Paulo: Paulus, 2020.

SANTAELLA, L. Semiótica Aplicada. São Paulo: Cengage Learning, 2018.

SANTOS, D. M. et al. Pentecostalismo, neopentecostalismo e teologia da prosperidade: Uma análise sobre a Igreja Mundial do Poder de Deus. Revista Unitas, Vitória, v. 5. n, 2, 2017.

SILVA JÚNIOR, I. B. da. Espaço, cultura e religião: um olhar para o neopentecostalismo underground. 2017. Dissertação (Mestrado em Geografia) - Universidade Federal de Uberlândia, Ituiutaba, 2017. 
SILVA, J. R. da. Movimento neopentecostal, renovação carismática católica e a reformulação da teodiceia cristã na contemporaneidade. 2014. Tese (Doutorado em Sociologia) Universidade de Brasília, Brasília, DF, 2014.

SILVA, R. R. Identidade protestante e neopentecostalismo: um contraste das doutrinas da reforma. 2019. Monografia (Licenciatura em História) - Universidade Federal de Roraima, Boa Vista, 2019.

SPYER, J. O povo de Deus: quem são os evangélicos? Por que eles importam? São Paulo: Geração, 2020.

TELUSHKIN, J. Jewish Literacy: The most important things to know about the jewish religion, its people, and its history. Revised ed. New York: HarperCollins, 2010. 